\title{
Experimental Production of Biogas using Co-Digestion of Organic Waste
}

\author{
N.Karanthi Rekha, Sathish Kumar, A.Krishna Priya, CH.Mounika
}

\begin{abstract}
Environmental pollution is one of the major problems plaguing the modern world today. The environment and the various elements in the environment need energy to meet their need. So there is a need to produce energy from different sources. Solid Waste is one such material that can be used as a source for deriving energy. The studies on conversion of solid waste to energy have resulted several alternatives including the biogas production from biodegradable organic waste. There are several alternatives in the estimation of biogas yield from bio degradable fraction of solid waste. The different types of biodegradable organic waste may comprises of cow dung, pig waste, poultry manure, food waste, vegetable waste, kitchen waste etc [9]. The present study focuses on production of biogas using cow dung with vegetable waste and poultry manure. In this study, by doing experimentation it is observed that the production of biogas from co-digestion of different organic waste is more than individual waste. The highest yield of biogas is obtained from co-digestion of cow dung with poultry manure than co-digestion of cow dung with the vegetable waste. Waste produced after the production of biogas is used as natural fertilizers for the growth of crops and fields and it gives good yield. By experimentations like energy recovery from solid waste, the conservation of non renewable energy resources may be possible and it also helps to protect our environment [16].
\end{abstract}

KEY WORDS: pollution, biogas, co-digestion, cow dung, poultry waste, vegetable waste.

\section{INTRODUCTION}

Global Warming, Acid rain, Ozone layer depletion, Deforestation, Loss of Biodiversity, Desertification, Depletion of non-renewable energy sources, Water pollution, Rapid population growth, Waste Disposal, Food and Water storage are the major environmental problems which cause damage to the environment [1]. So, there is a need to protect our environment through the control and mitigation of the pollution responsible for the above solid issues of environmental problems. The solid waste management is planned channeling of solid wastes from generating point or source to ultimate disposal either for an end use or no use of the entire process [4].

The ISWM (Integrated Solid Waste Management) should focus on planning and effective implementation at all the efficient basics of SWM program. The ISWM involves

Revised Version Manuscript Received on 10 September, 2019.

N.Karanthi Rekha, Assistant Professor, Department of civil engineering, SRK Institute of Technology, Vijayawada, Andhra Pradesh, India.

Sathish Kumar, Associate Professor, Department of civil engineering, MARRI LAXMAN REDDY Institute of Technology and management, Hyderabad, Telangana, India.

A.Krishna Priya,Assistant Professor, Department of civil engineering, SRK Institute of Technology, Vijayawada, Andhra Pradesh, India.

CH.Mounika, Assistant Professor, Department of civil engineering, AMRITA SAI Institute of science and Technology, Vijayawada, Andhra Pradesh, India. techniques, the application of suitable policies, technologies and management programs covering all types of solid waste from all sources to achieve specific waste management objective. Management of Solid Waste reduces the adverse impacts on the human health, environment and improved quality of life and support economic development [13]. Major concern for most of the people in these days is the use and availability of energy. Most of the people spend a large portion of energy of their earnings on gas, power and oil. These fossil fuels are being continuously used to large extent. Because these forms of energy are non-renewable, their availability will continue to decrease and costs will continue to go up. This has led to search for new energy sources. In this study, we are produced new energy that is biogas from different solid wastes that is cow dung, poultry waste, and vegetable waste [9].

\section{METHODOLOGY}

\subsection{Study area}

This work was done at the biogas plant. It was located at ghantasala, Krishna district, Andhra Pradesh. In our research work, it was a fixed dome type bio-digester. By using fixed dome type bio-digester, calculation of volume of bio-gas generation per day is done. The length, width, height of inlet and outlet tank is $0.8 \mathrm{~m}, 0.74 \mathrm{~m}, 0.55 \mathrm{~m}$ respectively (refer figure 1). The diameter of digestion tank is $2.75 \mathrm{~m}$ and volume of digestion tank is $43.23 \mathrm{~m} 3$.the pressure gauge is used for the measurement of volume of biogas as shown in figure2.

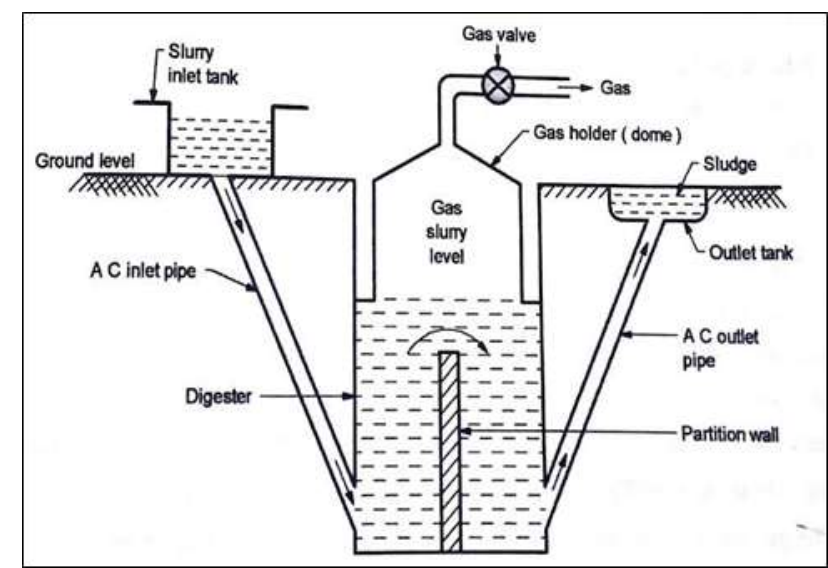

Figure 1: fixed dome type digestion tank

Published By: Blue Eyes Intelligence Engineering \& Sciences Publication 


\section{Experimental Production of Biogas using Co-Digestion of Organic Waste}

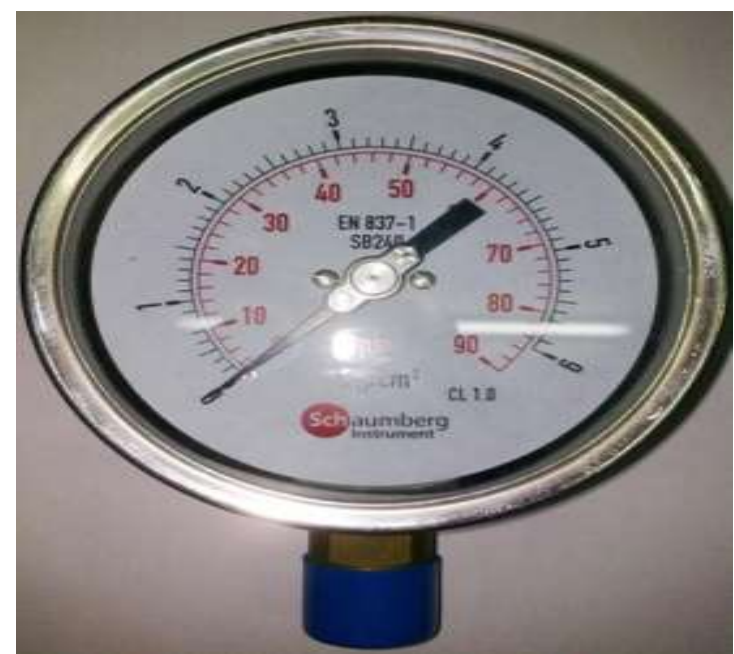

Figure 2: pressure gauge

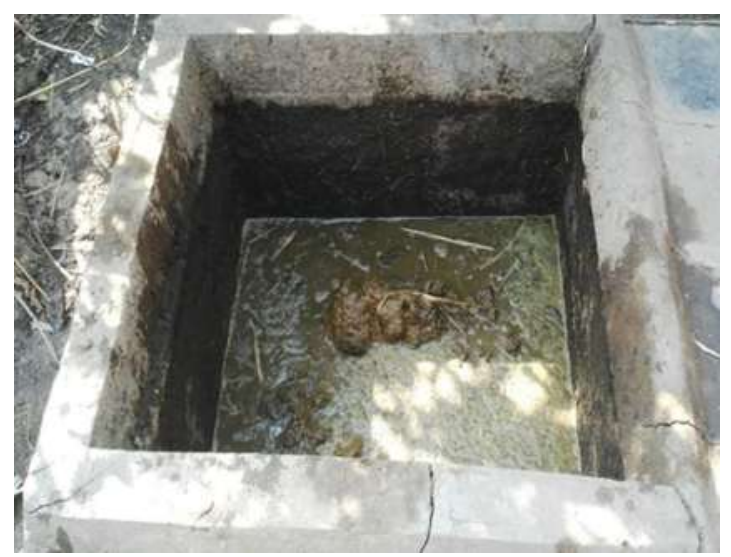

Figure 3: feeding of organic waste in inlet chamber

\section{SAMPLE PREPARATION AND EXPERIMENTATION}

3.1. The Process of Experimentation with Cow Dung and water in 1:1 Ratio (Experiment I)

Take the Cow dung and weight of the Cow dung is measured. Dilute the Cow dung by adding known quantity of water in bucket as 1:1 ratio of Cow dung. Temperature of reactor is taken as 370C for anaerobic digestion (Ref: Waste Water Engineering by Metcalf and Eddy 2003). After every 24 hours, the release of the gas at outlet will be measured. The release of the biogas will be raised up to a point and then decreases simultaneously. The digested Cow dung was collected at outlet and it is used as fertilizer.

On the first day (22/03/2019) $0.10 \mathrm{~m} 3$ of cow dung and add $0.10 \mathrm{~m} 3$ of water is added. Mixed the cow dung and water in the inlet of the biogas plant. Temperature of the digester tank is taken as 370C for anaerobic digestion (Ref: Waste Water Engineering by Metcalf and Eddy 2003). The slurry is released into the digester tank through inlet of the biogas. The pressure gauge is fixed at the outlet of the biogas plant. On second day the reading of the pressure gauge is recorded. Volume of bio-gas generation is calculated by using ideal gas equation.

$$
\mathrm{P} * \mathrm{~V}=\mathrm{n} * \mathrm{R} * \mathrm{~T}
$$

Where $\mathrm{P}=$ Pressure of the biogas.

$\mathrm{V}=$ Volume of the biogas released.

$\mathrm{n}=$ Number of moles.

$\mathrm{R}=$ specific gas constant.
$\mathrm{T}=$ Temperature

3.2 The Process of Experimentation with Co-digestion of Cow Dung and Poultry Waste in 1:1 Ratio (Experiment II)

Take the Cow dung and Poultry manure. Weight of the Cow dung and Poultry manure is measured. Mix the Cow dung and Poultry manure with water in 1:1 ratio. Dilute the Cow dung and Poultry manure by adding known quantity of water in bucket as 1:1 ratio of Cow dung and Poultry manure. Temperature of reactor is taken as $370 \mathrm{C}$ for anaerobic digestion (Ref: Waste Water Engineering by Metcalf and Eddy 2003). After every 24 hours, the release of the gas at outlet will be measured. The release of the biogas will be raised up to a point and then decreases simultaneously. The digested Cow dung and Poultry manure was collected at outlet and it is used as fertilizer.

On the first day (01/04/2019) $0.05 \mathrm{~m} 3$ of cow dung and $0.05 \mathrm{~m} 3$ of poultry manure are taken. Add $0.10 \mathrm{~m} 3$ of water. Mix the cow dung, poultry manure and water in the inlet of the biogas plant. Temperature of the digester tank is taken as $370 \mathrm{C}$ for anaerobic digestion (Ref: Waste Water Engineering by Metcalf and Eddy 2003). The slurry is released into the digester tank through inlet of the biogas. The pressure gauge is fixed at the outlet of the biogas plant. On second day the reading of the pressure gauge is recorded. Volume of bio-gas generation is calculated by using ideal gas equation.

$\mathrm{P} * \mathrm{~V}=\mathrm{n} * \mathrm{R} * \mathrm{~T}$

Where $\mathrm{P}=$ Pressure of the biogas.

$\mathrm{V}=$ Volume of the biogas released.

$\mathrm{n}=$ Number of moles.

$\mathrm{R}=$ specific gas constant.

$\mathrm{T}=$ Temperature

3.3. The Process of Experimentation with Co-digestion of Cow Dung and Vegetable Waste in 1:1 Ratio (Experiment III)

Take the Cow dung and Vegetable Waste. Weight of the Cow dung and Vegetable Waste is measured. Mix the Cow dung and Vegetable Waste with water in 1:1 ratio. Dilute the Cow dung and Vegetable Waste by adding known quantity of water in bucket as 1:1 ratio of Cow dung and Vegetable waste. Temperature of reactor is taken as $370 \mathrm{C}$ for anaerobic digestion (Ref: Waste Water Engineering by Metcalf and Eddy 2003). After every 24 hours, the release of the gas at outlet will be measured. The release of the biogas will be raised up to a point and then decreases simultaneously. The digested Cow dung and Vegetable waste was collected at outlet and it is used as fertilizer.

On the first day (27/04/2019) $0.05 \mathrm{~m} 3$ of cow dung and $0.05 \mathrm{~m} 3$ of vegetable waste is taken. Add $0.10 \mathrm{~m} 3$ of water. Mix the cow dung, vegetable waste and water in the inlet of the biogas plant. Temperature of the digester tank is taken as $370 \mathrm{C}$ for anaerobic digestion (Ref: Waste Water Engineering by Metcalf and Eddy 2003). The slurry is released into the digester tank through inlet of the biogas. The pressure gauge is fixed at the outlet of the biogas plant. On second day the reading of the pressure gauge is noted. Volume of bio-gas generation is calculated by using ideal gas equation. 
$\mathrm{P} * \mathrm{~V}=\mathrm{n} * \mathrm{R} * \mathrm{~T}$

Where $\mathrm{P}=$ Pressure of the biogas.

$\mathrm{V}=$ Volume of the biogas released.

$\mathrm{n}=$ Number of moles.

$\mathrm{R}=$ specific gas constant.

\section{RESULT AND DISCUSSIONS}

\subsection{Experiment I}

Biogas productions from anaerobic decomposition of cow dung from 22/03/2016 to 27/03/2016 are noted. The maximum production of biogas is released at 4 th day i.e. $0.049 \mathrm{~m} 3$.the results are shown in table 1. Graph1 shows biogas production Vs time from 22/03/2016 to 27/03/2016.

Table 1: Biogas production from Cow Dung and water in 1:1 Ratio

\begin{tabular}{|l|l|l|l|l|l|l|l|}
\hline S.NO & $\begin{array}{l}\text { TYPE OF } \\
\text { WASTE }\end{array}$ & DATE & $\begin{array}{l}\text { PRESSURE } \\
\left(\mathrm{N} / \mathrm{m}^{2}\right)\end{array}$ & $\begin{array}{l}\text { TEMPERATURE } \\
(\mathrm{k})\end{array}$ & $\mathrm{R}$ & $\begin{array}{c}\mathrm{n} \\
(\mathrm{mol})\end{array}$ & $\begin{array}{l}\mathrm{V}=\mathrm{nRT} / \mathrm{P} \\
\left(\mathrm{m}^{3}\right)\end{array}$ \\
\hline 1 & COWDUNG & $22 / 03 / 19$ & 968.40 & 310 & 0.082 & 1 & 0.026 \\
\hline 2 & COWDUNG & $23 / 03 / 19$ & 917.43 & 310 & 0.082 & 1 & 0.028 \\
\hline 3 & COWDUNG & $24 / 03 / 19$ & 815.49 & 310 & 0.082 & 1 & 0.031 \\
\hline 4 & COWDUNG & $25 / 03 / 19$ & 509.68 & 310 & 0.082 & 1 & 0.049 \\
\hline 5 & COWDUNG & $26 / 03 / 19$ & 662.58 & 310 & 0.082 & 1 & 0.037 \\
\hline 6 & COWDUNG & $27 / 03 / 19$ & 866.46 & 310 & 0.082 & 1 & 0.029 \\
\hline
\end{tabular}

Graph 1: Biogas production from Cow Dung and water in 1:1 Ratio

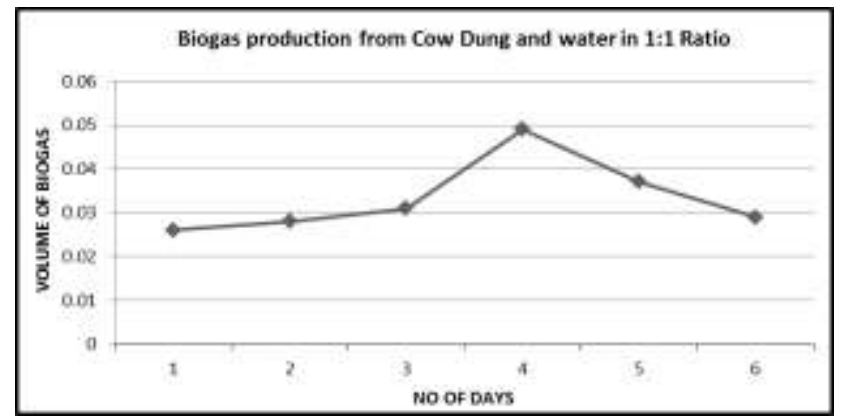

\subsection{Experiment II}

Biogas productions from anaerobic decomposition of cow dung with poultry waste from $01 / 04 / 2019$ to $24 / 04 / 2019$ are noted. The maximum production of biogas is released at 13 th day i.e. $0.063 \mathrm{~m} 3$.the results are shown in table 2 . Graph 2 shows biogas production Vs time from 01/04/2019 to 24/04/2019.

Table 2: Biogas production from co digestion of Cow Dung with poultry waste and water in 1:1 Ratio

\begin{tabular}{|c|c|c|c|c|c|c|c|}
\hline $\begin{array}{l}\mathrm{S} . \\
\mathrm{N} \\
\mathrm{O}\end{array}$ & $\begin{array}{l}\text { TYPE OF } \\
\text { WASTE }\end{array}$ & DATE & $\begin{array}{l}\text { PRESSURE } \\
\left(\mathrm{N} / \mathrm{m}^{2}\right)\end{array}$ & $\begin{array}{l}\text { TEMPERATURE } \\
\text { (k) }\end{array}$ & $\mathrm{R}$ & $\begin{array}{l}\mathrm{n} \\
(\mathrm{mol})\end{array}$ & $\begin{array}{l}\mathrm{V}=\mathrm{nRT} / \mathrm{P} \\
\left(\mathrm{m}^{3}\right)\end{array}$ \\
\hline 1 & $\begin{array}{l}\text { COWDUNG+POULTRY } \\
\text { WASTE }\end{array}$ & $01 / 04 / 19$ & 2140.67 & 310 & 0.082 & 1 & 0.0121 \\
\hline 2 & $\begin{array}{l}\text { COWDUNG+POULTRY } \\
\text { WASTE }\end{array}$ & $02 / 04 / 19$ & 2038.73 & 310 & 0.082 & 1 & 0.0127 \\
\hline 3 & $\begin{array}{l}\text { COWDUNG+POULTRY } \\
\text { WASTE }\end{array}$ & $03 / 04 / 19$ & 1936.79 & 310 & 0.082 & 1 & 0.013 \\
\hline 4 & $\begin{array}{l}\text { COWDUNG+POULTRY } \\
\text { WASTE }\end{array}$ & $04 / 04 / 19$ & 1732.92 & 310 & 0.082 & 1 & 0.014 \\
\hline 5 & $\begin{array}{l}\text { COWDUNG+POULTRY } \\
\text { WASTE }\end{array}$ & $05 / 04 / 19$ & 1630.98 & 310 & 0.082 & 1 & 0.015 \\
\hline 6 & $\begin{array}{l}\text { COWDUNG+POULTRY } \\
\text { WASTE }\end{array}$ & $06 / 04 / 19$ & 1223.24 & 310 & 0.082 & 1 & 0.021 \\
\hline 7 & $\begin{array}{l}\text { COWDUNG+POULTRY } \\
\text { WASTE }\end{array}$ & $07 / 04 / 19$ & 1121.3 & 310 & 0.082 & 1 & 0.023 \\
\hline 8 & $\begin{array}{l}\text { COWDUNG+POULTRY } \\
\text { WASTE }\end{array}$ & $08 / 04 / 19$ & 866.46 & 310 & 0.082 & 1 & 0.029 \\
\hline 9 & $\begin{array}{l}\text { COWDUNG+POULTRY } \\
\text { WASTE }\end{array}$ & $09 / 04 / 19$ & 764.52 & 310 & 0.082 & 1 & 0.033 \\
\hline 10 & $\begin{array}{l}\text { COWDUNG+POULTRY } \\
\text { WASTE }\end{array}$ & $10 / 04 / 19$ & 713.55 & 310 & 0.082 & 1 & 0.036 \\
\hline 11 & $\begin{array}{l}\text { COWDUNG+POULTRY } \\
\text { WASTE }\end{array}$ & $11 / 04 / 19$ & 611.62 & 310 & 0.082 & 1 & 0.042 \\
\hline
\end{tabular}


Experimental Production of Biogas using Co-Digestion of Organic Waste

\begin{tabular}{|c|l|l|l|l|l|l|l|}
\hline 12 & $\begin{array}{l}\text { COWDUNG+POULTRY } \\
\text { WASTE }\end{array}$ & $12 / 04 / 19$ & 509.68 & 310 & 0.082 & 1 & 0.050 \\
\hline 13 & $\begin{array}{l}\text { COWDUNG+POULTRY } \\
\text { WASTE }\end{array}$ & $13 / 04 / 19$ & 407.74 & 310 & 0.082 & 1 & 0.063 \\
\hline 14 & $\begin{array}{l}\text { COWDUNG+POULTRY } \\
\text { WASTE }\end{array}$ & $14 / 04 / 19$ & 458.71 & 310 & 0.082 & 1 & 0.056 \\
\hline 15 & $\begin{array}{l}\text { COWDUNG+POULTRY } \\
\text { WASTE }\end{array}$ & $15 / 04 / 19$ & 560.65 & 310 & 0.082 & 1 & 0.040 \\
\hline 16 & $\begin{array}{l}\text { COWDUNG+POULTRY } \\
\text { WASTE }\end{array}$ & $16 / 04 / 19$ & 662.58 & 310 & 0.082 & 1 & 0.039 \\
\hline 17 & $\begin{array}{l}\text { COWDUNG+POULTRY } \\
\text { WASTE }\end{array}$ & $17 / 04 / 19$ & 815.49 & 310 & 0.082 & 1 & 0.031 \\
\hline 18 & $\begin{array}{l}\text { COWDUNG+POULTRY } \\
\text { WASTE }\end{array}$ & $18 / 04 / 19$ & 917.43 & 310 & 0.082 & 1 & 0.028 \\
\hline 19 & $\begin{array}{l}\text { COWDUNG+POULTRY } \\
\text { WASTE }\end{array}$ & $19 / 04 / 19$ & 968.39 & 310 & 0.082 & 1 & 0.026 \\
\hline 20 & $\begin{array}{l}\text { COWDUNG+POULTRY } \\
\text { WASTE }\end{array}$ & $20 / 04 / 19$ & 1325.17 & 310 & 0.082 & 1 & 0.019 \\
\hline 21 & $\begin{array}{l}\text { COWDUNG+POULTRY } \\
\text { WASTE }\end{array}$ & $21 / 04 / 19$ & 1427.11 & 310 & 0.082 & 1 & 0.018 \\
\hline 22 & $\begin{array}{l}\text { COWDUNG+POULTRY } \\
\text { WASTE }\end{array}$ & $22 / 04 / 19$ & 1529.05 & 310 & 0.082 & 1 & 0.016 \\
\hline 23 & $\begin{array}{l}\text { COWDUNG+POULTRY } \\
\text { WASTE }\end{array}$ & $23 / 04 / 19$ & 1834.86 & 310 & 0.082 & 1 & 0.014 \\
\hline 24 & $\begin{array}{l}\text { COWDUNG+POULTRY } \\
\text { WASTE }\end{array}$ & $24 / 04 / 19$ & 2242.60 & 310 & 0.082 & 1 & 0.011 \\
\hline
\end{tabular}

dung with vegetable waste from 27/04/2019 to 12/05/2019

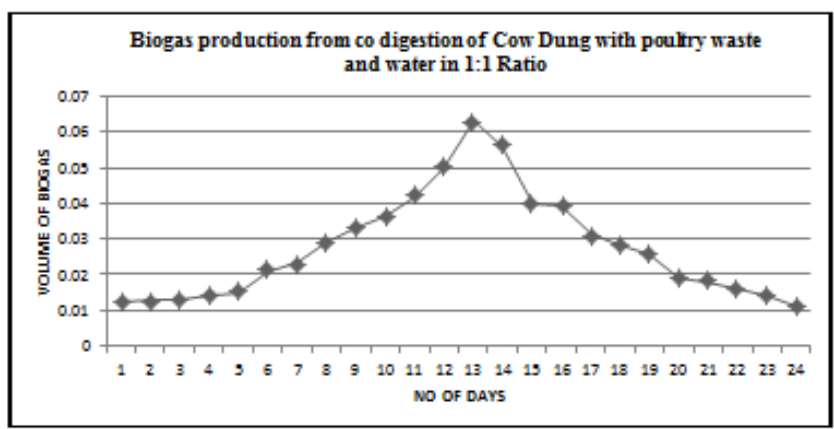
are noted. The maximum production of biogas is released at 10th day i.e. $0.052 \mathrm{~m} 3$.the results are shown in table 3. Graph 3 shows biogas production Vs time from 27/04/2019 to $12 / 05 / 2019$.

Graph 2: Biogas production from co digestion of Cow

Dung with poultry waste and water in 1:1 Ratio

\subsection{Experiment III}

Biogas productions from anaerobic decomposition of cow

Table 3: Biogas production from co digestion of Cow Dung with vegetable waste and water in 1:1 Ratio

\begin{tabular}{|c|c|c|c|c|c|c|c|}
\hline S.NO & $\begin{array}{l}\text { TYPE OF } \\
\text { WASTE }\end{array}$ & DATE & $\begin{array}{c}\text { PRESSU } \\
\text { RE } \\
\left(\mathrm{N} / \mathrm{m}^{2}\right) \\
\end{array}$ & $\begin{array}{l}\text { TEMPERATUR } \\
\text { E } \\
\text { (k) }\end{array}$ & $\mathrm{R}$ & $\begin{array}{r}n \\
(\mathrm{~mol})\end{array}$ & $\begin{array}{c}\mathrm{V}=\mathrm{nRT} / \mathrm{P} \\
\left(\mathrm{m}^{3}\right)\end{array}$ \\
\hline 1 & $\begin{array}{l}\text { COWDUNG+VEGETABL } \\
\text { E WASTE }\end{array}$ & $27 / 04 / 19$ & 2038.73 & 310 & 0.082 & 1 & 0.012 \\
\hline 2 & $\begin{array}{l}\text { COWDUNG+VEGETABL } \\
\text { E WASTE }\end{array}$ & $28 / 04 / 19$ & 1834.86 & 310 & 0.082 & 1 & 0.014 \\
\hline 3 & $\begin{array}{l}\text { COWDUNG+VEGETABL } \\
\text { E WASTE }\end{array}$ & $29 / 04 / 19$ & 1019.36 & 310 & 0.082 & 1 & 0.025 \\
\hline 4 & $\begin{array}{l}\text { COWDUNG+VEGETABL } \\
\text { E WASTE }\end{array}$ & $30 / 04 / 19$ & 948.01 & 310 & 0.082 & 1 & 0.027 \\
\hline 5 & $\begin{array}{l}\text { COWDUNG+VEGETABL } \\
\text { E WASTE }\end{array}$ & $01 / 05 / 19$ & 886.85 & 310 & 0.082 & 1 & 0.029 \\
\hline 6 & $\begin{array}{l}\text { COWDUNG+VEGETABL } \\
\text { E WASTE }\end{array}$ & $02 / 05 / 19$ & 815.49 & 310 & 0.082 & 1 & 0.031 \\
\hline
\end{tabular}


International Journal of Recent Technology and Engineering (IJRTE) ISSN: 2277-3878, Volume-8, Issue-2S11, September 2019

\begin{tabular}{|l|l|l|l|l|l|l|l|}
\hline 7 & $\begin{array}{l}\text { COWDUNG+VEGETABL } \\
\text { E WASTE }\end{array}$ & $03 / 05 / 19$ & 744.13 & 310 & 0.082 & 1 & 0.034 \\
\hline 8 & $\begin{array}{l}\text { COWDUNG+VEGETABL } \\
\text { E WASTE }\end{array}$ & $04 / 05 / 19$ & 652.39 & 310 & 0.082 & 1 & 0.039 \\
\hline 9 & $\begin{array}{l}\text { COWDUNG+VEGETABL } \\
\text { E WASTE }\end{array}$ & $05 / 05 / 19$ & 570.84 & 310 & 0.082 & 1 & 0.045 \\
\hline 10 & $\begin{array}{l}\text { COWDUNG+VEGETABL } \\
\text { E WASTE }\end{array}$ & $06 / 05 / 19$ & 489.29 & 310 & 0.082 & 1 & 0.052 \\
\hline 11 & $\begin{array}{l}\text { COWDUNG+VEGETABL } \\
\text { E WASTE }\end{array}$ & $07 / 05 / 19$ & 519.87 & 310 & 0.082 & 1 & 0.049 \\
\hline 12 & $\begin{array}{l}\text { COWDUNG+VEGETABL } \\
\text { E WASTE }\end{array}$ & $08 / 05 / 19$ & 560.65 & 310 & 0.082 & 1 & 0.045 \\
\hline 13 & $\begin{array}{l}\text { COWDUNG+VEGETABL } \\
\text { E WASTE }\end{array}$ & $09 / 05 / 19$ & 642.20 & 310 & 0.082 & 1 & 0.040 \\
\hline 14 & $\begin{array}{l}\text { COWDUNG+VEGETABL } \\
\text { E WASTE }\end{array}$ & $10 / 05 / 19$ & 693.17 & 310 & 0.082 & 1 & 0.037 \\
\hline 15 & $\begin{array}{l}\text { COWDUNG+VEGETABL } \\
\text { E WASTE }\end{array}$ & $11 / 05 / 19$ & 723.75 & 310 & 0.082 & 1 & 0.035 \\
\hline 16 & $\begin{array}{l}\text { COWDUNG+VEGETABL } \\
\text { E WASTE }\end{array}$ & $12 / 05 / 19$ & 744.13 & 310 & 0.082 & 1 & 0.034 \\
\hline
\end{tabular}

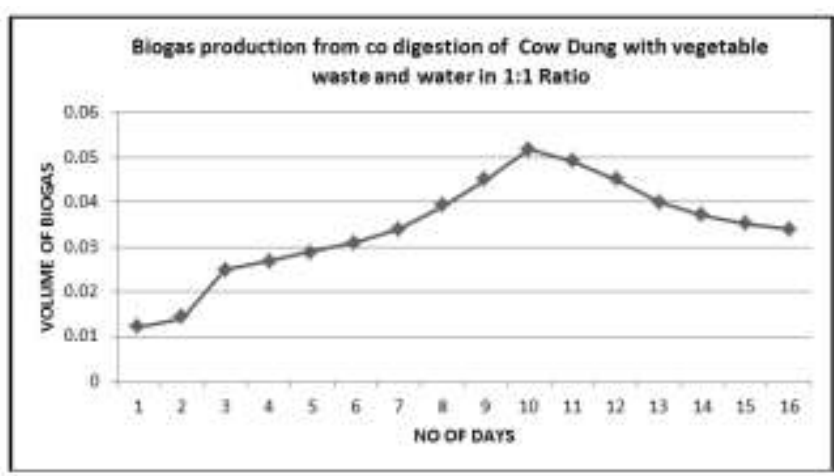

Graph 3: Biogas production from co digestion of Cow Dung with vegetable waste and water in 1:1 Ratio

The experiments were performed in the fore mentioned procedures, the results were analyzed. The details of the results, analysis and discussions are presented. From the experimentation, the highest biogas yield is obtained from the co-digestion of cow dung with poultry manure.

\section{CONCLUSIONS}

The organic fraction of solid waste obtaining from different activities may be used for several purposes including recycling, reusing and energy recovery. Energy recovery is one of the important aspects of waste management and the production of biogas from organic waste is one among them. The experimentation is done on co-digestion of cow dung with poultry manure and vegetable waste. The highest yield of biogas is obtained from the co-digestion of cow dung with poultry manure i.e. $0.063 \mathrm{~m} 3$. Based on the above experiments the following conclusions are made.

- The production of biogas using 1:1 ratios of cow dung and water is $0.049 \mathrm{~m} 3$.

- The production of biogas using co-digestion of cow dung with poultry manure using $1: 1$ ratio is $0.063 \mathrm{~m} 3$.

- The production of biogas using co-digestion of cow dung with vegetable waste using $1: 1$ ratio is $0.052 \mathrm{~m} 3$.

- It shows that the co-digestion of cow dung with poultry manure will produce highest yield of biogas compared to the co-digestion of cow dung with vegetable waste.

- The production of biogas from co-digestion of wastes is more than the individual waste.

\section{REFERENCES}

1. Attila M, Valeria N "Biogas and Energy production by utilization of different agricultural wastes", Acta polytechnic Hungarica, Vol: 9, No:6 (2012).

2. Adrian E.C, Ioana I and Cermengasnproducgacita C "Experimental results concerning biogas production through anaerobic fermentation, based on different waste biomass" (2010).

3. Aremu M.O,Agarry S.E "Comparison of Biogas production from cow dung and pig dung under mesophillic conditions", International Journal of Engineering and Science (IRJES), Vol:1, Pg:16-21 (2012).

4. Baba S.U.I.A and Nasir I, "Anaerobic Digestion of cowdung for biogas production", ARPN Journal of Engineering and Sciences, Vol: 7, No:2 (2012).

5. Bouallagui $\mathrm{H}$, Touhami $\mathrm{Y}$, Ben cheikhR, Hamdi $\mathrm{M}$ "Bioreactor performance in anaerobic digester of fruit and vegetable wastes", Process Biochemistry, Vol: 40,pg: 989-995 (2004).

6. Belhadj S, Karouach F, El. Bari H, Joute Y "The biogas production from mesophillic anaerobic digestion of Vinasse", IOSR-JESTFT (Journal of Environmental Science, Toxicology and Food Technology, Vol:5, pg: 72-77 (2013)

7. Chaiprasert $\mathrm{P}$ "Biogas production from Agricultural wastes in Thailand", Journal of Sustainable Energy and Environmental Issue (2011).

8. Dlabaja and Malatak $\mathrm{J}$ "Optimization of anaerobic fermentation of Kitchen waste", Res. Agr. Eng, Vol: 59, No(1), pg:1-8 (2013).

9. Forhad I.A.I, Khan M.Z.H, Sarkar M.A. R, Ali S.M "Development of biogas processing from cowdung, poultry waste, and water hyacinth", International Journal of Natural and Applied Science, vol: 2(1), pg: 13-17 (2013). 
10. IbnAbubakar $\mathrm{B}$ and Ismail $\mathrm{N}$ "Investigated the effectiveness of cow dung for biogas production (2012).

11. Joaquin P.D, Mulallira B, Viammey T "Biogas production from kitchen waste/Refuse", Department of Chemistry and Food processing technology (2008).

12. Narayani T.G and GamathiPriya P "Biogas production through mixed fruit wastes biodegradation", Journal of Science Indian Research, Vol: 71, pg:217-220(2012).

13. Naila A, Anwar B.M "Biogas production from vegetable waste at Thermophillic conditions" (2012).

14. Nengwe F.W et.al. "The production of biogas from cow dung, pig and chicken manures and mixture of water hyacinth-cow dung" (2010).

15. Nathan $\mathrm{C}$ and Pragasen $\mathrm{P}$ " biogas production and design of food waste to energy system for the urban environment", Elsevier (2011).

16. Ripon K.S, Md. Fahiar R and Hasan A "Production of biogas from Mesophillic Anaerobic Digestion of kitchen waste", International Journal of advanced Renewable Energy Resarch, Vol:1, pg:628-633 (2010).

17. wastewater engineering by METCALF AND EDDY 2003 by MCGRAW HILL EDUCATION PVT LTD. 